\title{
ANALISIS PELAKSANAAN ANGGARAN BELANJA DESA \\ TAHUN ANGGARAN 2016 DI WILAYAH KABUPATEN KENDAL
}

\author{
Penta Widyartati, Marhamah, Edy Susanto \\ Program Studi Akuntansi, STIE SEMARANG
}

\begin{abstract}
The village income and expenditure budget is the responsibility of the village management holder to provide information on activities to the village community on the management of village funds and the implementation of village program plans financed with village money in APBDesa contains income, expenditure and village financing.

Broadly speaking, the income of the village is divided into two, namely the Original Revenue and Transfer Revenue. The Original Revenue consists of the results of the village and self-help businesses. Transfer revenues consist of village funds, tax and retribution fees, allocation of village funds, and financial assistance from both provinces and districts. As for the expenditure is divided into 4 areas, namely the field of administration of the village, the field of implementation of village development, the field of village community development, and the empowerment of village communities. In this study to be studied is limited only to the implementation of village development and empowerment of rural communities.

From the research results it is known that from the total use of funds for the field of development and community empowerment, the allocation of funds for village development amounted to Rp 8.207.305.895 or reached 96\%, far greater than for the field of community empowerment which only $4 \%$ or Rp. 323.528.405.

In terms of Law, it is found that there is a discrepancy in the implementation of the village budget usage, in Chapter IX Law no. 6 year 2014 on Rural Development and Rural Area Development. In Chapter IX of Law No. 6, Part One of Village Development Article 78 paragraph 3 states that village development as referred to in paragraph (2) prioritizes togetherness, kinship and mutual cooperation in order to realize the mainstreaming of peace and social justice. In this article shows that development is principled mutual cooperation and kinship. But in practice and in the report of Revenue and Expenditure Budget Village still found labor point. This indicates a non-conformity with the principle of mutual cooperation as described in Chapter IX above.
\end{abstract}

Keywords: Village Fund, APBDes, mutual cooperation

\section{ABSTRAK}

Anggaran pendapatan dan belanja desa adalah pertanggungjawaban dari pemegang manajemen desa untuk memberikan informasi tentang segala aktifitas dan kegiatan desa kepada masyarakat desa pemerintah atas pengelolaan dana desa dan pelaksanaan berupa rencana-rencana program yang dibiayai dengan uang desa. Dalam APBDesa berisi pendapatan, belanja dan pembiayaan desa.

Secara garis besar, pendapatan desa dibagi menjadi dua, yaitu Pendapatan Asli Daerah dan Pendapatan Transfer. Pendapatan Asli Daerah terdiri dari hasil usaha desa dan swadaya. Pendapatan transfer terdiri dari dana desa, bagian pajak dan retribusi, alokasi dana desa, dan bantuan keuangan baik dari propinsi maupun kabupaten. 
Sedangkan untuk belanja dibagi menjadi 4 bidang, yaitu bidang penyelenggaraan pemerintah desa, bidang pelaksanaan pembangunan desa, bidang pembinaan masyarakat desa, dan bidang pemberdayaan masyarakat desa. Dalam penelitian ini yang akan diteliti dibatasi hanya pada pelaksanaan untuk pembangunan desa dan pemberdayaan masyarakat desa.

Dari hasil penelitian diketahui bahwa dari total penggunaan dana untuk bidang pembangunan dan pemberdayaan masyarakat, alokasi dana untuk pembangunan desa adalah sebesar Rp 8.207.305.895 atau mencapai 96\%, jauh lebih besar daripada untuk bidang pemberdayaan masyarakat yang hanya $4 \%$ atau Rp. 323.528.405.

Dari segi Undang-undang, ditemukan adanya ketidaksesuaian pelaksanaan penggunaan anggaran desa ini, yaiatu pada Bab IX UU No. 6 tahun 2014 tentang Pembangunan Desa dan Pembangunan Kawasan Perdesaan. Pada Bab IX UU No, 6 Bagian Kesatu Pembangunan Desa Pasal 78 ayat 3 menyatakan bahwa pembangunan desa sebagaimana dimaksud ayat (2) mengedepankan kebersamaan, kekeluargaan dan kegotongroyongan guna mewujudkan pengarusutamaan perdamaian dan keadilan sosial. Pada pasal ini menunjukkan bahwa pembangunan berprinsip kegotongroyongan dan kekeluargaan. Tetapi dalam praktek dan di dalam laporan Anggaran Pendapatan dan Belanja Desa masih ditemukan point tenaga kerja. Hal ini menunjukkan adanya ketidak sesuaian dengan prinsip kegotongroyongan yang diutamakan seperti pada bab IX di atas.

Kata kunci : Dana Desa, APBDes, kegotongroyongan

\section{Pendahuluan}

Salah satu perubahan besar yang terjadi di desa-desa atau kelurahan di Indonesia pada tahun 2015 ialah mulai dikucurkannya dana desa sebagai realisasi dari berlakunya Undang Undang Desa (UU No 6 tahun 2014). Pemerintah telah mengucurkan dana desa sebanyak Rp. 20,70 trilyun pada tahun 2015 untuk dikucurkan kepada 74.093 desa. Tahun anggaran 2016 jumlah kucuran dana desa justru semakin meningkat yakni menjadi Rp.46,98 trilyun (Kompas, 10 April 2016). Propinsi Jawa Tengah pada tahun 2016 menerima kucuran dana sebanyak Rp. 5 trilyun, diperuntukan sebanyak 7.809 desa (www.djpk.kemenkeu.go.id/web/ attachments/article/608/ DANADESA 2016).

Dari dana tersebut, alokasi untuk Kabupaten Kendal adalah sebesar Rp. 166 milyar dengan alokasi yang berbeda-beda untuk setiap desanya tergantung dari kriterianya. Kriteria tersebut berdasarkan luas desa, jumlah penduduk, jumlah penduduk miskin, dan jangkauan desa atau letak geografis dari ibukota Kecamatan. (http://jateng.tribunnews.com/2016/05/01/ alokasi-dana-desa-tahap-pertama-untuk-kendal-cair-sebesar-rp-164-miliar).

Kucuran dana tersebut dimaksud untuk mendukung program program pembangunan dan pemberdayaan masyarakat desa sebagaimana diamanatkan oleh Undang Undang Desa. Dengan kata lain dana desa dimaksud untuk menopang upaya meningkatkan kesejahteraan masyarakat desa melalui program-program yang diperlukan sesuai dengan masalah dan 
aspirasi masyarakat desa. Diakui atau tidak berlakunya Undang Undang Desa membawa perubahan besar bagi tata kelola masyarakat maupun birokrasi desa.

\section{Masalah Penelitian}

Berbagai masalah yang akan dijawab dalam penelitian ini adalah:

1. Bagaimana pelaksanaan penggunaan Dana Desa tahun anggaran 2016 di wilayah kecamatan Kabupaten Kendal untuk program
1) Pembangunan Desa
2) Pemberdayaan masyarakat desa

2. Bagaimana pelaksanaan penggunaan dana desa tahun anggaran 2016 bagi pembangunan desa untuk
1) Pengembangan potensi ekonomi lokal
2) Pemenuhan kebutuhan dasar
3) Pemanfaatan sumberdaya dan lingkungan secara berkelanjutan
4) Pembangunan sarana prasarana desa

3. Bagaimana pelaksanaan penggunaan dana desa tahun anggaran 2016 untuk pemberdayaan masyarakat desa dengan orientasi
1) Mendukung kegiatan ekonomi Badan Usaha Milik Desa
2) Peningkatan kualitas proses perencanaan desa
3) Peningkatan kapasitas kelompok masyarakat
4) Penyelenggaraan promosi kesehatan
5) Penyelenggaraan promosi pendidikan

4. Seberapa besar kesempatan kerja yang tercipta sebagai implementasi Anggaran Pendapatan dan Belanja Desa tahun anggaran 2016 di kelurahan-kelurahan di wilayah Kabupaten Kendal

5. Seberapa besar kesempatan kerja yang tercipta sebagai implementasi Anggaran Pendapatan dan Belanja Desa tahun anggaran 2016 di kelurahan-kelurahan di wilayah kabupaten Kendal yang dinikmati warga masyarakat desa setempat

\section{Kajian Teoritis}

1. Pembangunan Desa

Pembangunan desa merupakan upaya pembangunan yang berorientasi pada upaya peningkatan standar hidup yang lebih baik. Hal tersebut disebabkan karena kenyataan menunjukkan bahwa standar hidup di pedesaan terbukti masih lebih rendah dibanding dengan 
standar hidup di perkotaan. Pemerintahan Susilo Bambang Yudoyono (2009 - 20014 ) telah memetakan dan menetapkan berbagai hal berkenaan dengan pembangunan perdesaan.

Berkaitan dengan permasalahan yang pada umumnya dihadapi masyarakat pedesaan adalah

1) Terbatasnya alternatif lapangan kerja. Mayoritas kegiatan ekonomi dan mata pencaharian masyarakat desa adalah di sektor pertanian. Kontribusi sektor pertanian dari tahun ke tahun cenderung menurun.

2) Lemahnya keterkaitan kegiatan ekonomi secara struktural maupun spasial. Hal tersebut tampak dengan kondisi lemahnya keterkaitan antara sektor pertanian (produk) dengan sektor industri (pengolahan) dan sektor jasa

3) Tingginya resiko kerentanan yang dihadapi petani dan pelaku usaha di pedesaan.

4) Rendahnya aset yang dikuasai masyarakat desa

5) Rendahnya tingkat pelayanan sarana dan prasarana

6) Rendahnya kualitas SDM masyarakat pedesaan

7) Meningkatnya konversi lahan pertanian subur bagi peruntukan lain

8) Lemahnya kelembagaan dan organisasi masyarakat desa

9) Lemahnya koordinasi lintas bidang dalam pengembangan kawasan pedesaan.

Selanjutnya Pemerintah SBY (2009 - 2014) telah menetapkan sasaran pembangunan pedesaan yakni:

1) Meningkatnya peran dan kontribusi kawasan pedesaan sebagi basis pertumbuhan ekonomi nasional

2) Terciptanya lapangan kerja berkualitas di pedesaan khususnya lapangan kerja nonpertanian yang ditandai dengan pengurangan angka penggangguran terbuka

3) Meningkatnya kesejahteraan masyarakat pedesaan yang ditandai dengan berkurangnya jumlah penduduk miskin serta meningkatnya taraf pendidikan dan kesehatan terutama perempuan dan anak

4) Meningkatnya kualitas dan kuantitas infrastruktur di kawasan permukiman

5) Meningkatnya akses, kontrol dan partisipasi seluruh elemen masyarakat dalam kegiatan pembangunan pedesaan.

Bertitik tolak dari permasalahan dan sasaran program pembangunan pedesaan tersebut, program pembangunan pemerintah SBY (2009 - 20014) terkait dengan pembangunan pedesaan menetapkan kebijakan sebagai berikut:

1) Mendorong terciptanya lapangan kerja berkualitas di pedesaan dengan merangsang pertumbuhan aktivitas ekonomi non-pertanian (industri pedesaan dan jasa penunjang), diversifikasi usaha pertanian. 
2) Meningkatkan promosi dan pemasaran produk-produk pertanian dan pedesaan guna meningkatkan kontinuitas pasokan

3) Memperluas akses masyarakat, terutama kaum perempuan ke sumber- sumber daya produktif

4) Meningkatkan keberdayaan masyarakat pedesaan melalui peningkatan kualitas baik sebagai insan maupun sebagai sumberdaya pembangunan

5) Meningkatkan kesejahteraan masysarakat pedesaan dengan memenuhi hak- hak dasar atas pelayanan pendidikan dan kesehatan serta meminimalkan resiko kerentanan

6) Mengembangkan praktek- praktek budidaya pertanian dan usaha non- pertanian.

Selanjutnya ditetapkan program pembangunan pedesaan mencakup :

1) Peningkatan pemberdayaan masyarakat dengan 12 kegiatan pokok.

2) Program pengembangan ekonomi lokal dengan 13 kegiatan pokok

3) Program terkait dengan peningkatan infrastruktur pedesaan dengan empat (4) kegiatan pokok

4) Program terkait dengan peningkatan kualitas sumberdaya manusia di pedesaan dengan 7 kegiatan pokok dan

5) Program perlindungan dan konservasi sumberdaya alam pedesaan dengan lima (5) kegiatan pokok.

2. Perencanaan Pembangunan Desa Berbasis UU Desa No 6 Th 2014

Masyarakat desa merupakan bagian dari masyarakat Indonesia yang memiliki sejumlah hak. Mengenai hal ini UU Desa No 6 tahun 2014 telah menetapkan sejumlah hak masyarakat desa (Ps 68, UU 6 Th 2014) yakni:

1) Meminta dan mendapatkan informasi dari Pemerintah Desa serta pmengawasi kegiatan pemerintahan desa, pelaksanaan pembangunan desa, pembinaan kemasyarakatan desa dan pemberdayaan masyarakat desa.

2) Memperoleh pelayanan yang sama dan adil

3) Menyampaikan aspirasi, saran dan pendapat lisan atau tertulis secara bertanggng jawab tentang kegiatan penyelenggaraan Pemerintahan Desa, pelaksanaan Pembangunan Desa, pembinaan masyarakat desa dan pemberdayaan masyarakat desa.

4) Memilih dan dipilih dan atau ditetapkan menjadi kepala desa, perangkat desa, anggota Badan Permusyawaratan Desa atau anggota lembaga kemasyarakatan Desa 
Selanjutnya ditetapkan pula dalam UU Desa mengenai perencanaan pembangunan Desa sebagaimana disebutkan pada Ps 79 UU No 6 tahun 2014 yakni:

1) Pemerintah Desa menyusun perencanaan Pembangunan Desa sesuai kewenangannya dengan mengacu pada perencanaan pembangunan Kota/kabupaten

2) Perencanaan pembangunan desa tersebut disusun secara berjangka meliputi

- Rencana Pembangunan Jangka Menengah (RPJM) Desa untuk jangka waktu enam (6) tahun

- Rencana Pembangunan tahunan atau disebut Rencana Kerja Pemerintah Desa (RKPD) sebagai penjabaran RPJM-D untuk jangka waktu satu (1) tahun.

3) RPJMD dan RKPD merupakan pedoman dalam penyusunan Anggaran Pendapatan dan Belanja Desa

4) Perencanaan Pembangunan Desa diselenggarakan dengan mengikut sertakan masyarakat Desa

5) Pemerintah Desa wajib menyelenggarakan musyawarah perencanaan Pembangunan Desa (Musrengbangdes) (Ps 80 UU No 6 Th 2014)

6) Musrengbangdes menetapkan prioritas, program, kegiatan dan kebutuhan Pembangunan Desa

7) Prioritas, program, kegiatan dan kebutuhan Pembangunan Desa berdasar penilaian terhadap kebutuhan masyarakat desa yang meliputi:

- Peningkatan kualitas dan akses terhadap pelayanan dasar

- Pembangunan dan pemeliharaan infrastruktur dan lingkungan berdasar kemampuan teknis dan sumberdaya lokal

- Pengembangan ekonomi pertanian berskala produktif

- Pengembangan dan pemanfaatan teknologi tepat guna untuk mekajuan ekonomi

- Peningkatan kualitas ketertiban dan ketentraman masyarakar Desa berdasarkan kebutuhan masyarakat Desa

3. Musyawarah Rencana Pembangunan Desa (Musrenbangdes)

Sebagaimana ditetapkan dalam Undang Undang Desa No 6 tahun 2014 mengenai Pembangunan Desa dalam mana penyusunan perencanaannya melibatkan masyarakat. Keterlibatan masyarakat tampak pada antara lain tahapan pelaksanaan Musrengbangdes. 
Tahapan Musrengbangdes diawali dengan kegiatan yang dikenal sebagai Rembug Warga (Petunjuk Pelaksanaan Musyawarah Perencanaan Pembangunan, kota Semarang, 2014).

Dalam Petunjuk Pelaksanaan Musrengbangdes kota Semarang tahun 2014 terkait dengan Rembug Warga dapat dicatat hal-hal penting sebagai berikut:

1) Rembug Warga merupakan forum musyawarah warga di tingkat RW sebagai wadah melakukan jajak kebutuhan bagi penyiapan usulan kegiatan pembangunan tahunan di tingkat kelurahan.

2) Kegiatan Rembug Warga merupakan satu kesatuan yang tidak terpisahkan dengan Musrengbangdes (kelurahan)

3) Peserta Rembug Warga adalah

- Unsur kelurahan dan Lembaga Pemberdayaan Masyarakat Kelurahan (sebagai Tim Pendukung dan nara sumber)

- Pengurus Badan Keswadayaan Masyarakat (BKM)

- Pengurus RT dan RW

- Tokoh masyarakat/ agama, perwakilan perempuan, perwakilan warga miskin

- Tokoh pemuda

- Kepala sekolah swasta atau negeri yang ada di wilayah kelurahan

- Pengurus PKK, Pos PAUD, Posyandu dan Karangtaruna di tingkat RW

4) Musrengbangkel (Musyawarah Rencana Pembangunan Kelurahan)

Mengenai Musyawarah Rencana Pembangunan Kelurahan sebagaimana ditetapkan pada Petunjuk Pelaksanaan Musrengbangdes Kota Semarang 2014 dapat dicatat beberapa hal sebagai berikut :

Tujuan Musrengbangkel:

- Menampung dan membahas kebutuhan masyarakat yang diperoleh dari Rembug Warga di tingkat RW

- Menyepakati prioritas kebutuhan/masalah yang akan dilaksanakan sendiri oleh anggaran kelurahan

- Menyepakati usulan prioritas masalah dan kegiatan yang akan diusulkan ke Musrengbang kecamatan untuk menjadi kegiatan SKPD yang dibiayai melalui APBD (kota/provinsi) atau melalui mekanisme pemberian hibah dan bantuan sosial

- Memadukan dan mensinergikan perencanaan di tingkat kelurahan 
Mengenai peserta ditentukan sebagai berikut. Peserta Musrengbang kelurahan terdiri dari unsur:

- Pemerintah kelurahan (Lurah, Sekretaris dan para Kasi)

- Delegasi RW

- Organisasi Masyarakat Kelurahan

- Pengurus Lembaga Pemberdayaan Masysrakat (LPMK)

\section{Metodologi}

Penelitian ini adalah penelitian yang bersifat deskriptif. Penelitian deskriptif dimaksudkan untuk mengeksplorasi dan klarifikasi mengenai suatu fenomena atau kenyataan sosial, dengan jalan mendeskripsikan sejumlah variabel yang berkenaan dengan masalah yang diteliti. Penelitian ini tidak dimaksudkan untuk menguji hipotesis tertentu, melainkan lebih pada menggambarkan apa adanya suatu gejala, variabel, atau keadaan.

Penelitian ini dilakukan untuk menggambarkan tentang pelaksanaan anggaran belanja desa ini dilakukan di wilayah kabupaten Kendal, yaitu di desa-desa yang diambil secara acak di empat kecamatan, yaitu di kecamatan Boja, kecamatan Kaliwungu Selatan, kecamatan Gemuh dan kecamatan Boja. Pengumpulan data dilakukan mulai dari tanggal 4 Mei 2017 sampai dengan tanggal 2 Agustus 2017.

Adapun proses pengumpulan data diawali dengan mengajukan ijin penelitian ke Badan Perencanaan Penelitian dan Pengembangan (Baperlitbang) Kabupaten Kendal. Dari Baperlitbang ijin penelitian diserahkan ke Kecamatan-kecamatan yang ditunjuk untuk berkoordinasi, mengajukan ijin dan menentukan desa-desa yang akan dijadikan objek penelitian.

\section{Pembahasan}

Dari pengumpulan data yang dilakukan, yang berhasil dikumpulkan adalah sebanyak 19 data dari 19 desa tentang penggunaan anggaran desa yang terdiri dari 5 desa di kecamatan Kaliwungu Selatan, 6 desa di wilayah kecamatan Kendal, 5 desa di kecamatan Gemuh dan 3 desa di kecamatan Boja. Dalam pengumpulan data diketahui bahwa desa-desa di wilayah kecamatan Kendal tidak menerima dana berupa kas. Untuk memenuhi kebutuhan desa, kepala desa mengajukan permohonan yang setelah disetujui akan diberikan berupa barang yang dibutuhkan. 
Dengan mekanisme seperti itu maka kelurahan-kelurahan di wilayah kecamatan Kendal tidak mempunyai kebebasan dalam penggunaan dana. Karena kelurahan-kelurahan tersebut tidak menerima dana berupa kas, sehingga dalam penelitian ini semua kelurahan sampel yang berada di wilayah kecamatan Kendal tidak dimasukkan sebagai obyek dalam penelitian ini. Sehingga dari 19 sampel yang dikumpulkan, hanya 10 desa yang dapat digunakan sebagai obyek penelitian yaitu desa-desa di kecamatan Boja, kecamatan Gemuh dan kecamatan Kaliwungu Selatan.

Dari kecamatan, penelitian dilanjutkan dengan pengumpulan data ke desa-desa yang dituju untuk mengumpulkan data-data yang diperlukan untuk menjelaskan pertanyaanpertanyaan yang menjadi variabel dalam penelitian. Pertanyaan-pertanyaan penelitian yang dimaksud adalah sebagai berikut:

1. Bagaimana pelaksanaan penggunaan Dana Desa tahun anggaran 2016 di wilayah kecamatan Kabupaten Kendal

Total penggunaan anggaran desa tahun anggaran 2016 pada desa-desa sampel untuk alokasi pembangunan dan pemberdayaan masyarakat desa adalah Rp. 8.530.834.300 yang tersebar pada beberapa desa sebagai berikut:

Tabel 1

Alokasi Dana Pembangunan Desa dan Pemberdayaan Masyarakat Desa Pada Masing-masing desa

\begin{tabular}{cllrrr}
\hline No & Kelurahan & Kecamatan & $\begin{array}{c}\text { Alokasi } \\
\text { Pembangunan } \\
\text { Desa }\end{array}$ & $\begin{array}{c}\text { Alokasi } \\
\text { pemberdayaan } \\
\text { masyarakat desa }\end{array}$ & \multicolumn{1}{c}{ Total } \\
\hline 1 & Magelung & Kaliwungu Selatan & 876.518 .760 & 43.890 .000 & 920.408 .760 \\
3 & Sukomulyo & Kaliwungu Selatan & 707.954 .154 & 17.000 .000 & 724.954 .154 \\
6 & Purwogondo & Boja & 750.777 .831 & 25.000 .000 & 775.777 .831 \\
7 & Kaligading & Boja & 710.141 .010 & 30.000 .000 & 740.141 .010 \\
8 & Bebengan & Boja & 1.030 .485 .465 & 51.720 .000 & 1.082 .205 .465 \\
9 & Poncorejo & Gemuh & 823.463 .534 & 17.500 .000 & 840.963 .534 \\
10 & Pucangrejo & Gemuh & 993.947 .141 & 39.360 .000 & 1.033 .307 .141 \\
11 & Cepokomulyo & Gemuh & 688.901 .000 & 37.954 .405 & 726.855 .405 \\
12 & Krompaan & Gemuh & 820.602 .829 & 7.270 .000 & 827.872 .829 \\
13 & Triharjo & Gemuh & 804.514 .171 & 53.834 .000 & 858.348 .171 \\
\hline \multicolumn{7}{c}{ Total } & & $\mathbf{8 . 2 0 7 . 3 0 5 . 8 9 5}$ & $\mathbf{3 2 3 . 5 2 8 . 4 0 5}$ & $\mathbf{8 . 5 3 0 . 8 3 4 . 3 0 0}$ \\
\hline
\end{tabular}


Dari susunan data dari tabel di atas maka dapat disajikan dalam tabel distribusi frekuensi sebagai berikut :

Tabel 5.2

Distribusi frekuensi Alokasi Dana Pembangunan Desa dan Pemberdayaan Masyarakat Desa Statistics

\begin{tabular}{lrrr}
\hline & PembangunanDesa & $\begin{array}{c}\text { Pemberdayaan } \\
\text { Masyarakat }\end{array}$ & \multicolumn{1}{c}{ Total } \\
\hline $\mathrm{N} \quad$ Valid & 10 & 10 & 10 \\
Missing & 0 & 0 & 0 \\
Mean & $8,21 \mathrm{E} 8$ & 32352840,50 & $8,53 \mathrm{E} 8$ \\
Median & $8,13 \mathrm{E} 8$ & 33977202,50 & $8,34 \mathrm{E} 8$ \\
Mode & $688901000^{\mathrm{a}}$ & $7270000^{\mathrm{a}}$ & $724954154^{\mathrm{a}}$ \\
Minimum & 688901000 & 7270000 & 724954154 \\
Maximum & 1030485465 & 53834000 & 1082205465 \\
Sum & 8207305895 & 323528405 & 8530834300 \\
\hline
\end{tabular}

a. Multiple modes exist. The smallest value is shown

Sedangkan akumulasi penggunaan dana untuk pembangunan dan pemberdayaan seluruh desa sampel ditunjukkan dalam diagram sebagai berikut:

\section{Gambar 1}

Alokasi penggunaan dana untuk pembangunan desa dan pemberdayaan masyarakat desa

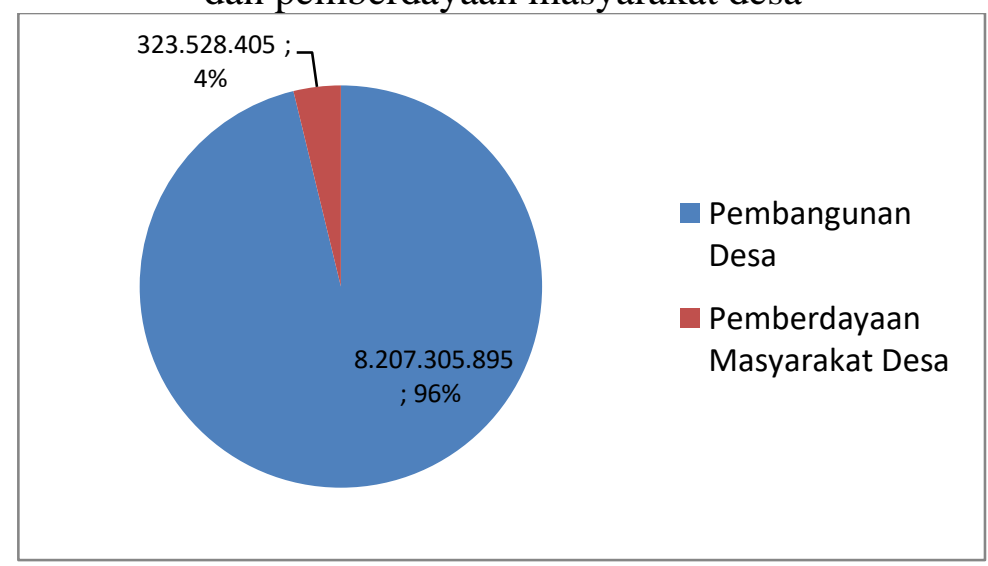

Dari data-data tersebut di atas maka dapat dijelaskan bahwa:

1) Pembangunan Desa

Dari 10 desa sampel penggunaan dana anggaran desa sebagian besar dialokasikan pembangunan desa, yang terdiri dari jalan, saluran irigasi, pembangunan talud, pembangunan gorong-gorong, dan lain-lain. Dari total penggunaan anggaran untuk pembangunan desa dan pemberdayaan masyarakat desa sejumlah Rp. 8.530.834.300, 96\% atau Rp. 8.207.305.895 digunakan untuk pembangunan desa. 
2) Pemberdayaan masyarakat desa

Penyerapan anggaran untuk alokasi pemberdayaan masyarakat untuk ke 10 desa sampel sangat kecil karena penggunaan anggaran pada hampir semua desa difokuskan pada pembangunan sarana dan prasarana. Penggunaan anggaran untuk pemberdayaan masyarakat untuk ke 10 desa sampel hanya Rp. 323.528 .405 atau hanya 4\% dari total pengeluaran pembangunan dan pemberdayaan desa yang mencapai angka Rp. 8.530.834.300. Penggunaan dana anggaran untuk pemberdayaan tersebut antara lain digunakan untuk program perencanaan pembangunan desa yang terdiri dari penyusunan RPJM Desa dan RKP Desa, program peningkatan kader pemberdayaan masyarakat desa, pelatihan teknologi tepat guna, pelatihan usaha dagang, peternakan dan pertanian, pemberian santunan masyarakat miskin dan yatim piatu, renovasi rumah warga miskin, program pelestarian budaya yang terdiri dari syukuran HUT RI, sedekah bumi, merti desa, tasyakuran hasil bumi, dan lain-lain.

2. Pelaksanaan penggunaan dana desa tahun anggaran 2016 bagi pembangunan desa Adapun alokasi penggunaan dana desa bagi pembangunan tiap-tiap desa adalah sebagai berikut:

Tabel 5.3

Alokasi Dana untuk Pembangunan Masing-masing Desa

\begin{tabular}{|c|c|c|c|c|c|c|c|}
\hline No & Desa & Kecamatan & $\begin{array}{c}\text { Pengembang } \\
\text { an potensi } \\
\text { ekonomi } \\
\text { lokal }\end{array}$ & $\begin{array}{l}\text { Pemenuhan } \\
\text { kebutuhan } \\
\text { dasar }\end{array}$ & $\begin{array}{c}\text { Pemanfaatan } \\
\text { sumber daya } \\
\text { lingkungan } \\
\text { berkelanjutan }\end{array}$ & $\begin{array}{c}\text { Pengembangan } \\
\text { sarana } \\
\text { prasarana desa }\end{array}$ & $\begin{array}{c}\text { Total } \\
\text { pembangunan } \\
\text { desa }\end{array}$ \\
\hline 1 & Magelung & $\begin{array}{l}\text { Kaliwungu } \\
\text { Selatan }\end{array}$ & & \multirow{10}{*}{$\begin{array}{r}13.300 .000 \\
193.683 .510\end{array}$} & \multirow{10}{*}{3.790 .000} & 876.518 .760 & 876.518 .760 \\
\hline 3 & Sukomulyo & $\begin{array}{l}\text { Kaliwungu } \\
\text { Selatan }\end{array}$ & & & & 707.954 .154 & 707.954 .154 \\
\hline 6 & Purwogondo & Boja & & & & 590.666 .759 & 607.756 .759 \\
\hline 7 & Kaligading & Boja & 258.750 .000 & & & 257.707 .500 & 710.141 .010 \\
\hline 8 & Bebengan & Boja & 190.346 .000 & & & 845.539 .465 & 1.035 .885 .465 \\
\hline 9 & Poncorejo & Gemuh & & & & 823.463 .534 & 823.463 .534 \\
\hline 10 & Pucangrejo & Gemuh & 2.300 .000 & & & 993.947 .141 & 996.247 .141 \\
\hline 11 & Cepokomulyo & Gemuh & - & & & 688.901 .000 & 688.901 .000 \\
\hline 12 & Krompaan & Gemuh & 14.000 .000 & & & 820.602 .829 & 834.602 .829 \\
\hline \multirow[t]{2}{*}{13} & Triharjo & Gemuh & 26.210 .165 & & & 804.514 .171 & 830.724 .336 \\
\hline & Total & & 491.606 .165 & 206.983 .510 & 3.790 .000 & 7.409 .815 .313 & 8.112 .194 .988 \\
\hline
\end{tabular}


Dari data di atas dapat disajikan dalam bentuk tabel distribusi frekuensi sebagai berikut:

Tabel 5.4

Distribusi Frekuensi Alokasi Dana untuk Pembangunan Desa

\begin{tabular}{|c|c|c|c|c|c|c|}
\hline \multicolumn{7}{|c|}{ Statistics } \\
\hline & & & & Pemanfaatan & & \\
\hline & & Pengembangan & Pemenuhan & Sumber Daya & Pengembangan & Total \\
\hline & & Potensi & Kebutuhan & Lingkungan & Sarana & Pembangunan \\
\hline & & Ekonomi Lokal & Dasar & Berkelanjutan & Prasarana Desa & Desa \\
\hline \multirow[t]{2}{*}{$\mathrm{N}$} & Valid & 10 & 10 & 10 & 10 & 10 \\
\hline & Missing & 0 & 0 & 0 & 0 & 0 \\
\hline \multicolumn{2}{|c|}{ Mean } & 49160616,50 & 20698351,00 & 379000,00 & $7,4098 \mathrm{E} 8$ & $8,1122 \mathrm{E} 8$ \\
\hline \multicolumn{2}{|c|}{ Median } & 1150000,00 &, 00 &, 00 & $8,1256 \mathrm{E} 8$ & $8,2709 \mathrm{E} 8$ \\
\hline \multicolumn{2}{|c|}{ Mode } & 0 & 0 & 0 & $2,58 \mathrm{E} 8$ & $6,08 \mathrm{E} 8$ \\
\hline \multicolumn{2}{|c|}{ Minimum } & 0 & 0 & 0 & $2,58 \mathrm{E} 8$ & $6,08 \mathrm{E} 8$ \\
\hline \multicolumn{2}{|c|}{ Maximum } & 258750000 & 193683510 & 3790000 & $9,94 \mathrm{E} 8$ & $1,04 \mathrm{E} 9$ \\
\hline \multicolumn{2}{|c|}{ Sum } & 491606165 & 206983510 & 3790000 & $7,41 \mathrm{E} 9$ & $8,11 \mathrm{E} 9$ \\
\hline
\end{tabular}

a. Multiple modes exist. The smallest value is shown

Sedangkan alokasi untuk keseluruhan dana pembangunan desa ditunjukkan dalam diagram sebagai berikut:

Gambar 2

Alokasi Dana untuk Pembangunan Desa

$\begin{array}{|ll|}\begin{array}{l}4.606 .165 ; \\ 6 \%\end{array} & \begin{array}{l}3.790 .000 ; 0 \% \\ \text { Pengembangan potensi } \\ \text { ekonomi lokal }\end{array} \\ & \begin{array}{l}\text { Pemenuhan kebutuhan } \\ \text { dasar }\end{array} \\ 7.409 .815 .3 & \begin{array}{l}\text { Pemanfaatan sumber } \\ \text { daya lingkungan } \\ \text { berkelanjutan }\end{array} \\ & \\ & \\ & \\ & \end{array}$

1) Pengembangan potensi ekonomi lokal

Pengembangan potensi ekonomi lokal pada desa-desa di wilayah kabupaten kendal ini masih terfokus pada pembangunan secara fisik yang berupa sarana dan prasarana yang mendukung masyarakat desa dalam melakukan aktifitas ekonominya. Pembangunan sarana prasarana pendukung ini dilakukan dalam bentuk pembangunan dan pemeliharaan saluran irigasi dan pembangunan serta pemeliharaan kios desa. Pembangunan sarana dan prasarana ini dilakukan karena desa-desa yang menjadi sampel mayoritas penduduknya bermata pencaharian petani. 
Pembangunan dan pemeliharaan kios desa dimaksudkan untuk memanfaatkan lahan milik desa yang letaknya strategis untuk perdagangan.

Selain pembangunan saluran irigasi dan pembangunan kios, pengembangan potensi ekonomi lokal ini dilakukan dengan membangun fasilitas berupa sumur artetis. Sumur artetis yang dibangun kemudian dikelola oleh masyarakat. Pendapatan dari sumur artetis itu digunakan untuk operasional sumur artetis itu sendiri dan juga untuk menunjang pembangunan fasilitas serupa di wilayah desa yang bersangkutan.

\section{2) Pemenuhan kebutuhan dasar}

Dari total penggunaan anggaran untuk pembangunan desa sebesar Rp. 8.112.194.988 ini, 2,5\% atau Rp. 206.983.510 diantaranya digunakan untuk membangun sarana dan prasarana untuk mendukung pemenuhan kebutuhan dasar. Pembangunan untuk pemenuhan kebutuhan dasar ini dilakukan dengan membangun dan merenovasi gedung PAUD. Pembangunan PAUD ini ditujukan untuk memenuhi kebutuhan pokok masyarakat di sekitar lokasi khususnya kebutuhan akan pendidikan usia dini. Dari pembangunan sarana ini masyarakat sekitar memperoleh 2 manfaat sekaligus yaitu mempermudah dan memperpendek akses masyarakat pada pendidikan anak usia dini, dan pada sisi lain juga dari pembangunan PAUD tersebut membutuhkan tenaga pendidik yang diambil dari warga sekitar.

3) Pemanfaatan sumberdaya dan lingkungan secara berkelanjutan

Alokasi dana pembangunan untuk pemanfaatan sumberdata dan lingkungan secara berkelanjutan untuk semua desa sampel sangat kecil, yaitu hanya mencapai Rp. 3.790.000 atau 0,05\% dari total penggunaan anggaran untuk pembangunan. Penggunaan dana untuk pemanfaatan sumberdaya dan lingkungan ini dialokasikan untuk pemeliharaan taman desa. Kecilnya penggunaan anggaran untuk pemanfaatan sumberdaya dan lingkungan ini dikarenakan desa-desa masih memfokuskan dana anggaran untuk membangun sarana dan prasarana desa.

\section{4) Pembangunan sarana prasarana desa}

Dari semua alokasi anggaran untuk pembangunan desa tersebut, alokasi pembangunan untuk pemenuhan sarana dan prasarana desa merupakan alokasi yang terbesar yaitu mencapai $91 \%$ dari total anggaran pembangunan desa atau mencapai Rp. 7.409.815.313.

Pembangunan sarana dan prasarana desa ini berupa pembangunan talud, pembetonan jalan, pembangunan bronjong, pengaspalan jalan, pemeliharaan jalan, dan pembangunan serta 
perbaikan sarana di balai desa. Dari pembangunan sarana dan prasarana ini diharapkan dapat memberikan kemudahan, kenyamanan dan keamanan warga dalam melakukan aktifitas sehari-hari.

3. Bagaimana pelaksanaan penggunaan dana desa tahun anggaran 2016 untuk pemberdayaan masyarakat desa dengan orientasi

Alokasi untuk pemberdayaan masyarakat desa untuk semua desa yang menjadi sampel sangatlah kecil, yaitu hanya $4 \%$ dari total dana untuk pembangunan dan pemberdayaan. Berikut adalah tabel yang menunjukkan distribusi penggunaan dana pemberdayaan desa untuk masing-masing desa:

Tabel 5.5

Alokasi Dana untuk Pemberdayaan Masing-masing Desa

\begin{tabular}{|c|c|c|c|c|c|c|c|c|}
\hline No & Desa & $\begin{array}{l}\text { Mendukung } \\
\text { kegiatan } \\
\text { BUMDes } \\
\text { (Ekonomi) }\end{array}$ & $\begin{array}{l}\text { Peningkatan } \\
\text { kualitas proses } \\
\text { perencanaan } \\
\text { desa }\end{array}$ & $\begin{array}{l}\text { Peningkatan } \\
\text { kapasitas } \\
\text { kelompok } \\
\text { masyarakat }\end{array}$ & $\begin{array}{l}\text { Penyeleng- } \\
\text { garaan } \\
\text { promosi } \\
\text { kesehatan }\end{array}$ & $\begin{array}{c}\text { Penyelenggaraan } \\
\text { promosi } \\
\text { pendidikan }\end{array}$ & Lain-lain & Total \\
\hline 1 & Magelung & & 5.000 .000 & & & & 38.890 .000 & 43.890 .000 \\
\hline 2 & Sukomulyo & & 2.000 .000 & 5.000 .000 & & & 10.000 .000 & 17.000 .000 \\
\hline 3 & Purwogondo & & & 5.000 .000 & & & 20.000 .000 & 25.000 .000 \\
\hline 4 & Kaligading & & & 5.000 .000 & & & 25.000 .000 & 30.000 .000 \\
\hline 5 & Bebengan & & & 5.000 .000 & & & 46.720 .000 & 51.720 .000 \\
\hline 6 & Poncorejo & & 5.000 .000 & 5.000 .000 & & & 7.500 .000 & 17.500 .000 \\
\hline 7 & Pucangrejo & & 9.250 .000 & 500.000 & & 6.110 .000 & 23.500 .000 & 39.360 .000 \\
\hline 8 & Cepokomulyo & 6.019 .154 & 5.000 .000 & & & & 26.935 .251 & 37.954 .405 \\
\hline 9 & Krompaan & & & 5.000 .000 & & 2.270 .000 & & 7.270 .000 \\
\hline \multirow[t]{2}{*}{10} & Triharjo & & 2.804 .000 & 5.000 .000 & & & 46.030 .000 & 53.834 .000 \\
\hline & Total & 6.019 .154 & 29.054 .000 & 35.500 .000 & - & 8.380 .000 & 244.575 .251 & 323.528 .405 \\
\hline
\end{tabular}


Distribusi frekuensi disajikan dalam tabel sebagai berikut:

Tabel 5.6

Distribusi Frekuensi Alokasi Dana untuk Pemberdayaan Masyarakat Desa

Statistics

\begin{tabular}{|c|c|c|c|c|c|c|c|}
\hline & $\begin{array}{l}\text { Mendukung } \\
\text { Kegiatan } \\
\text { BUMDes }\end{array}$ & $\begin{array}{l}\text { Peningkatan } \\
\text { Kualitas } \\
\text { Proses } \\
\text { Perencanaan } \\
\text { Desa } \\
\end{array}$ & $\begin{array}{c}\text { Peningkatan } \\
\text { Kapasitas } \\
\text { Kelompok } \\
\text { Masyarakat }\end{array}$ & $\begin{array}{l}\text { Penyeleng- } \\
\text { garaan } \\
\text { Promosi } \\
\text { Kesehatan }\end{array}$ & $\begin{array}{c}\text { Penyelenggara- } \\
\text { an Promosi } \\
\text { Pendidikan }\end{array}$ & Lain2 & Total \\
\hline N Valid & 10 & 10 & 10 & 10 & 10 & 10 & 10 \\
\hline Missing & 0 & 0 & 0 & 0 & 0 & 0 & 0 \\
\hline Mean & 601915,40 & 2905400,00 & 3550000,00 &, 00 & 838000,00 & 24457525,10 & 32352840,50 \\
\hline Median &, 00 & 2402000,00 & 5000000,00 &, 00 &, 00 & 24250000,00 & 33977202,50 \\
\hline Mode & 0 & 0 & 5000000 & 0 & 0 & $0^{\mathrm{a}}$ & $7270000^{\mathrm{a}}$ \\
\hline Minimum & 0 & 0 & 0 & 0 & 0 & 0 & 7270000 \\
\hline Maximum & 6019154 & 9250000 & 5000000 & 0 & 6110000 & 46720000 & 53834000 \\
\hline Sum & 6019154 & 29054000 & 35500000 & 0 & 8380000 & 244575251 & 323528405 \\
\hline
\end{tabular}

a. Multiple modes exist. The smallest value is shown

Gambar 5.3

Alokasi Dana untuk Pemberdayaan Masyarakat Desa

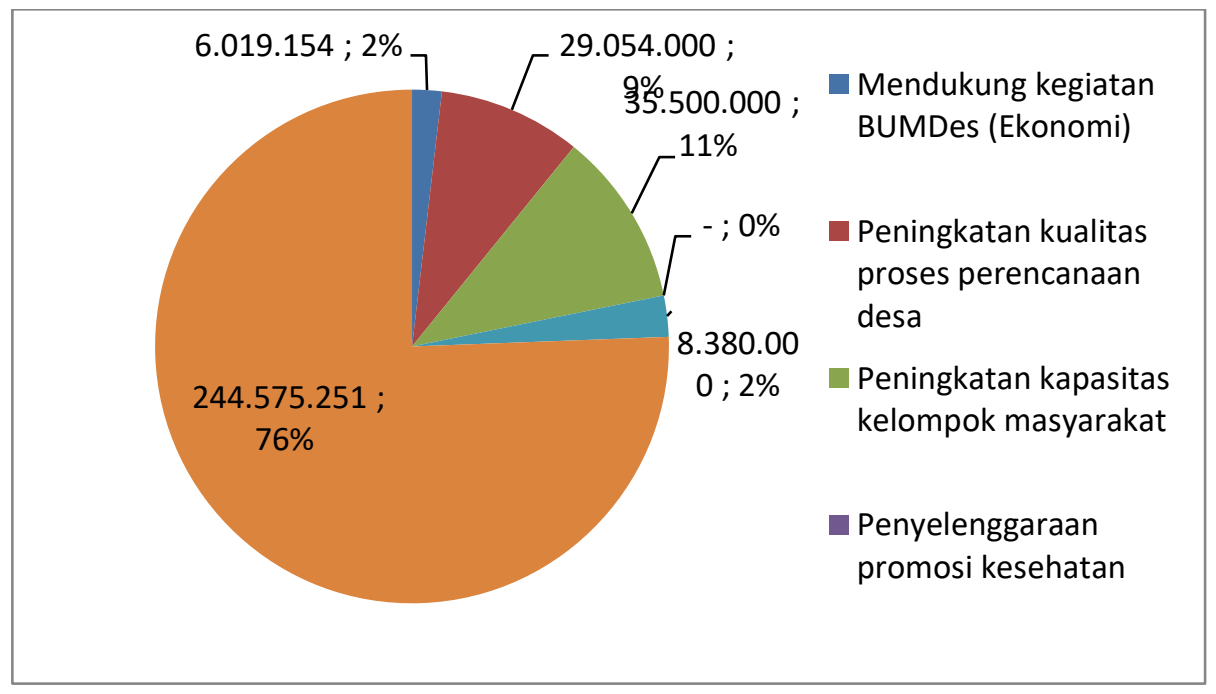

1) Mendukung kegiatan ekonomi Badan Usaha Milik Desa

Dari desa-desa sampel di wilayah kabupaten Kendal alokasi dana untuk mendukung kegiatan ekonomi Badan Usaha Milik Desa ini masih sangat kecil. Hal ini dikarenakan tidak semua desa memiliki usaha sendiri yang dikelola sebagai BUMDes. Dari semua sampel yang dikumpulkan tidak ada desa yang mempunyai BUMDes sehingga tidak ada kegiatan untuk mendukung kegiatan BUMDes tersebut. Kegiatan yang mendukung ekonomi yang dilakukan 
pada desa-desa sampel hanya ada pada desa Cepokomulyo kecamatan Gemuh. Kegiatan itu berupa pelatihan usaha dagang, peternakan dan pertanian. Dengan adanya pelatihan tersebut diharapkan akan meningkatkan semangat berwiraswasta pada masyarakat. Penggunaan anggaran untuk kegiatan badan usaha milik desa ini hanya mencapai 1,8\% atau Rp. 323.528.405 dari keseluruhan penggunaan pemberdayaan Rp. 323.528.405.

2) Peningkatan kualitas proses perencanaan desa

Peningkatan kualitas proses perencanaan desa di sini meliputi penyusunan RPJM Desa dan penyusunan RKP Des yang menyerap anggaran sebanyak Rp. 29.054.000 atau 9\% dari total pengeluaran untuk pemberdayaan masyarakat Rp. 323.528.405. Penyusunan RKP Desa dan RPJM Des ini berfungsi untuk merencanakan pembangunan desa untuk tahun anggaran berikutnya agar pembangunan tepat sasaran sesuai dengan prioritas dan kebutuhan masyarakat.

3) Peningkatan kapasitas kelompok masyarakat

Dari kelima variabel dalam penelitian ini peningkatan kapasitas kelompok masyarakat menyerap dana terbesar di antara kegiatan yang lain. Penyerapan dana ini mencapai Rp. 35.500 .000 atau $11 \%$ dari total pengeluaran untuk pemberdayaan masyarakat yang sebesar Rp. 323.528.405. Hanya ada satu kegiatan pemberdayaan untuk peningkatan kapasitas kelompok masyarakat yang dilakukan oleh desa-desa sampel, yaitu untuk pembentukan dan penguatan Kader Pemberdayaan Masyarakat Desa.

4) Penyelenggaraan promosi kesehatan

Dari semua desa sampel yang diambil tidak ada satu pun desa yang mengalokasikan anggaran untuk penyelenggaraan promosi kesehatan.

5) Penyelenggaraan promosi pendidikan

Kegiatan-kegiatan yang dilakukan di bidang promosi pendidikan ini antara lain operasional PAUD, operasional TK, pelatihan teknologi tepat guna, operasional lembaga keagamaan, pemberian beasiswa pada anak yang kurang mampu, dan pelatihan pembuatan pupuk cair. Kegiatan-kegiatan untuk promosi pendidikan ini menyerap dana sebesar Rp. 8.380.000 atau $2,6 \%$ dari total pengeluaran untuk pemberdayaan masyarakat.

Penggunaan dana pemberdayaan untuk alokasi kelima variabel hanyalah mencapai $24,4 \%$ atau Rp. 78.953.154 dari total dana untuk pemberdayaan yang Rp. 323.528.405. Sedangkan yang Rp. 244.575.251 atau 75,6\% nya dialokasikan pada kegiatan pemberdayaan lain lain diantaranya untuk kegiatan pemberian santunan kepada fakir miskin, pelestarian adat berupa kegiatan merti desa, tasyakuran hasil bumi, dan peringatan HUT RI. 
4. Seberapa besar kesempatan kerja yang tercipta sebagai implementasi Anggaran Pendapatan dan Belanja Desa tahun anggaran 2016 di kelurahan-kelurahan di wilayah Kabupaten Kendal

Peningkatan kesempatan kerja yang tercipta bagi masyarakat desa setempat sebagai implementasi dari penggunaan anggaran dan belanja desa tahun anggaran 2016 ini mengalami peningkatan khususnya untuk tenaga kerja langsung yang berhubungan dengan pembangunan sarana dan prasarana tersebut. Tenaga kerja langsung yang dimaksud adalah tenaga kasar yang ikut membangun sarana dan prasarana. Sehingga peningkatan kesempatan kerja signifikan yang tercipta hanya sementara, karena setelah pembangunan sarana dan prasarana berakhir, maka akan berakhir juga masa kerja pekerja kasar tersebut. Sedangkan untuk kenaikan tenaga kerja yang kontinyu tidak ada perubahan yang signifikan. Karena untuk pembangunan sarana dan prasarana yang membutuhkan tenaga kerja diupayakan untuk memberdayakan masyarakat di desa yang bersangkutan.

Selain dari tenaga kerja yang langsung menangani proyek pembuatan sarana dan prasarana ini, peningkatan juga terjadi pada penjualan bahan bangunan di kelurahan-kelurahan di wilayah kabupaten Kendal.

5. Seberapa besar kesempatan kerja yang tercipta sebagai implementasi Anggaran Pendapatan dan Belanja Desa tahun anggaran 2016 di kelurahan - kelurahan di wilayah kabupaten Kendal yang dinikmati warga masyarakat desa setempat

Sama seperti peningkatan penciptaan tenaga kerja di desa-desa di wilayah kabupaten Kendal, peningkatan penciptaan tenaga kerja di desa setempat juga tidak mengalami peningkatan yang signifikan terutama untuk tenaga kerja yang kontinyu. Hal ini dikarenakan karena sarana dan prasarana yang dibangun membutuhkan tenaga kerja yang tidak banyak untuk mengelola sarana dan prasarana yang telah dibangun tersebut.

Dari pembangunan PAUD hanya dibutuhkan tenaga kerja 4 orang pengajar dan untuk pengelolaan sumur artetis dibutuhkan 2 tenaga kerja untuk masing-masing sumur artetis yang dibangun.

\section{Penutup}

1. Dari penelitian tersebut maka dapat disimpulkan bahwa anggaran desa tersebut sebagian besar digunakan untuk membiayai pembangunan sarana dan prasarana secara fisik. Dengan pembangunan sarana dan prasarana tersebut maka penduduk akan lebih mudah dalam menjalankan aktifitas produktifnya sehingga produktifitas meningkat. 
Meningkatnya produktifitas akan meningkatkan kesejahteraan penduduk. Dari aktifitasaktifitas yang dilakukan dengan menggunakan anggaran desa pada desa-desa sampel sebagian besar digunakan untuk aktifitas non produktif. Sehingga dana yang sudah dialokasikan pada suatu sarana dan prasarana tersebut berhenti hanya pada sarana tersebut, dalam arti desa tidak mendapatkan pengembalian dana dari aktifitas-aktifitas yang sudah dilakukan. Sedangkan untuk aktifitas-aktifitas pembangunan yang lain desa sangat tergantung dengan kucuran dana dari pemerintah. Dari aktifitas-aktifitas pembangunan sarana dan prasarana tersebut menciptakan lapangan kerja bagi penduduk pada saat terjadinya pembangunan. Penciptaan lapangan kerja tersebut berakhir pada saat berakhirnya pembangunan sarana dan prasarana tersebut.

2. Pada Bab IX UU No. 6 tahun 2014 tentang Pembangunan Desa dan Pembangunan Kawasan Perdesaan Bagian Kesatu Pembangunan Desa Pasal 78 ayat 3 menyatakan bahwa pembangunan desa sebagaimana dimaksud ayat (2) mengedepankan kebersamaan, kekeluargaan dan kegotongroyongan guna mewujudkan pengarusutamaan perdamaian dan keadilan sosial. Pada pasal ini menunjukkan bahwa pembangunan berprinsip kegotongroyongan dan kekeluargaan. Tetapi dalam praktek dan di dalam laporan Anggaran Pendapatan dan Belanja Desa masih ditemukan point tenaga kerja. Hal ini menunjukkan adanya ketidak sesuaian dengan prinsip kegotongroyongan yang diutamakan seperti pada bab IX di atas.

\section{Daftar Pustaka}

Suparmoko, M., 1997. Ekonomi Sumber Daya Alam dan Lingkungan. BPFE UGM. Yogyakarta.

Undang -undang No 6 Tahun 2014 Tentang Desa

Peraturan Pemerintah No 12 Tahun 2011 Tentang Peraturan Pelaksanaan Undang-undang No 6 Tahun 2014 tentang Desa.

Halim, Abdul. 2015. Auditing Dasar-dasar Audit Laporan Keuangan Jilid 1. UPP STIM YKPN. Yogyakarta

Halim, Abdul. 2015. Auditing Dasar-dasar Audit Laporan Keuangan Jilid 2. UPP STIM YKPN. Yogyakarta 